\title{
Hyper-production of Alkaline Protease by Mutagenic Treatment of Bacillus subtilis M-9 using Agroindustrial Wastes in Submerged Fermentation
}

\author{
Sadia Javed ${ }^{1 *}$, Munazzah Meraj ${ }^{2}$, Shazia Anwer Bukhari', Rao Irfan ${ }^{3}$ and Saqib Mahmood ${ }^{4}$ \\ ${ }^{1}$ Department of Applied Chemistry \& Biochemistry, Government College University, Faisalabad, Pakistan \\ ${ }^{2}$ Department of Biochemistry, Peoples University of Medical and Health Sciences for Women, Nawabshah, Pakistan \\ ${ }^{3}$ Department of Pharmaceutics, University of Sindh, Jamshoroo, Pakistan \\ ${ }^{4}$ Department of Botany, Government College University, Faisalabad, Pakistan
}

\begin{abstract}
Green chemistry technologies are the powerful tool for the management of environmental wastes challenges Agro industrial residues are composed of complex polysaccharides that support the microbial growth for the production of useful products (enzymes, organic acids, drugs, etc.). Disposal and environment friendly management of these wastes has become a global priority. The aim of present investigation was to improve the alkaline protease yield by treating the parent Bacillus subtilis M-9 strain with different mutagens UV-irradiations, N-methyl-N-nitro$\mathrm{N}$-nitrosoguinidine (NTG), Ethidium bromide (EB), using agroindustrial wastes (banana stalk and corn stover) in submerged fermentation. Fifteen positive mutants were selected on skim milk agar plates for shake flask experiments BSU-5 mutant strain showed 81.21 $\pm 3.24 \mathrm{PU} / \mathrm{mL}$ alkaline protease activity higher than parent strain $(23.57 \pm 1.19$ $\mathrm{PU} / \mathrm{mL})$ in optimized fermentation medium. The fermentation profile like $\mathrm{pH}(9)$, temperature $\left(45^{\circ} \mathrm{C}\right)$, inoculum size $(2$ $\mathrm{mL}$ ), incubation time (24 hrs, and kinetic parameters such as $u\left(h^{-1}\right), Y_{p / s}, Y_{p / x}, Y_{x / s}, q_{s}, Q_{s}, q_{p}$ also confirmed the hyper proteolytic activity of alkaline protease produced from BSU-5 mutant strain over parent strain and other mutants. Finally, the BSU-5 mutant strain was immobilized by entrapping it in calcium alginate beads and agar. Alkaline protease production and stability of biocatalyst were investigated in both free and immobilized cells. It was concluded from the study, immobilized cells were more efficient for enzyme production then free cells when used repeatedly.
\end{abstract}

Keywords: Alkaline protease; Bacillus subtilis; Mutagenesis; Kinetics; Agro industrial wastes; Immobilization

\section{Introduction}

Synthetic and expensive substrates are being replaced by agroindustrial byproducts for the production of a wide range of value added biotechnological products [1,2]. Lignocellulosic biomass comprising forestry, agricultural and agro industrial wastes are abundant, renewable and inexpensive energy sources. Such wastes include a variety of materials such as sawdust, poplar trees, sugarcane bagasse and straws, stems, stalks, leaves, husks, shells and peels from cereals like rice, wheat, corn. Lignocelluloses wastes are accumulated every year in large quantities, causing environmental problems. However, due to their chemical composition based on sugars and other compounds of interest, they could be utilized for the production of a number of value added products, such as ethanol, food additives, organic acids, enzymes and others. Therefore, besides the environmental problems caused by their accumulation in the nature, the non use of these materials constitutes a loss of potentially valuable sources [3].

Protease is one of the most important industrial enzymes due to having some biotechnological interests. It account for about $60 \%$ of the total worldwide sale of enzymes, and is widely used in several industries that include leather processing, meat processing, dairy, preparation of organic fertilizer, silk industry, and also for the recovery of silver from used X-ray films [4]. They catalyze important proteolytic steps in tumor invasion, or in infection cycle of a number of pathogenic microorganisms. Among all proteases, alkaline proteases are robust in nature, and are primarily used as detergent additives [5]. Microbial proteases are produced from high yielding strains including species of Bacillus sp., Alcaligenes faecalis, Pseudomonas fluorescens and Aeromonas hydrophilia grown under submerged culture conditions. Among these, Bacillus sp. is the most important group of bacteria that are involved in the enzyme industry, and this bacterium is also known to produce proteolytic enzymes quite effectively [6]. The UV radiation is the most convenient of all mutagens to use, and it is also very easy to take effective safety precautions against it. It gives a high proposition of pyrimidine dimmers and includes all types of base pair substitutions [7]. The growth and enzyme production of the organism are strongly influenced by medium components like carbon and nitrogen sources. Besides the nutritional factors the cultural parameters like temperature, $\mathrm{pH}$, incubation time were also plays a major role in enzyme production [8], and as so the optimization of media components and cultural parameters is the primary task in a biological process [9]. The application of immobilized cells for the production of metabolic products by microorganisms has been widely studied and several valuable products such as enzymes, organic acids, amino acids, steroids, alcohol and antibiotics have been successfully obtained $[10,11]$. Immobilization of microbial cells offers several advantages, possible reuse of the cells, continuous operation and decreasing contamination without loss in biomass [12-14]. Immobilized cells have the ability to increase productivity and operational stability or reduced the delays involved in enzyme production. However, immobilized cells can show the modifications in physiology and biochemical composition as compared to suspended cells [10].

${ }^{*}$ Corresponding author: Sadia Javed, Department of Applied Chemistry and Biochemistry, Government College University, Faisalabad, 38000, Pakistan, Tel: 92-333-6510755; 92-41-8505391; E-mail: drsadiajaved@yahoo.com, diyajav1@yahoo.com

Received July 08, 2013; Accepted August 05, 2013; Published August 08, 2013

Citation: Javed S, Meraj M, Bukhari SA, Irfan R, Mahmood S (2013) Hyperproduction of Alkaline Protease by Mutagenic Treatment of Bacillus subtilis M-9 using Agroindustrial Wastes in Submerged Fermentation. J Microb Biochem Technol 5: 074-080. doi:10.4172/1948-5948.1000103

Copyright: ( $) 2013$ Javed S, et al. This is an open-access article distributed under the terms of the Creative Commons Attribution License, which permits unrestricted use, distribution, and reproduction in any medium, provided the original author and source are credited 
Therefore, the present study has been conducted with the main objective of investigating the production and optimization of alkaline protease produced, by using waste material to support the growth of parent and microbial strain of Bacillus subtilis. This information can added the value regarding indigenous strain improvement for the hyper production of alkaline protease by Bacillus subtilis, using waste materials and further immobilization of mutant cells for repeated batch culture or multiple uses of these immobilized cells. This process offers the inexpensive raw material and environment friendly management of waste. In contrast, extraction of this enzyme from natural sources not only increases the expenses of this enzyme, but also leads to low amount of this industrially important enzyme.

\section{Materials and Methods}

The strain of Bacillus subtilis M-9 was obtained from Institute of Microbiology, University of Agriculture, Faisalabad, Pakistan. The culture of $B$. subtilis M-9 (stock culture) was maintained in a refrigerator $\left(4^{\circ} \mathrm{C}\right)$ on nutrient agar medium (Oxoid, Hampshire, UK).

\section{Reagents and standards}

All analytical grade chemicals were purchased from either sigmaAldrich (Buchs, Switzerland) or E. Merck (Darmstadt, Germany). Microbial media were purchased from (Oxoid, Hampshire, UK).

\section{Preparation of substrate}

Corn stover obtained from CBC Rafhan Maize Products Faisalabad and banana stalk from fruit market were cut into pieces; oven dried, grounded to $40 \mathrm{~mm}$ mesh and stored in airtight plastic jars to avoid moisture.

\section{Mutagenic treatments}

The spores of $B$. subtilis M- $9\left(1 \times 10^{7}\right.$ spores $\left./ \mathrm{mL}\right)$ were exposed to UV irradiation by using UV lamp (Phillips, $20 \mathrm{~W}, \lambda_{360}$, distance of the lamp from the petri plates was $20 \mathrm{~cm})$. The sample $(1 \mathrm{~mL})$ was withdrawn after 30 minutes duration till 180 minutes. The optimum dose was selected by preparing the survival data $[15,16]$. The stock solutions of ethidium bromide (Sigma-Aldrich, UK) and N-methyl-N-nitro$\mathrm{N}$-nitrosoguinidine (Sigma-Aldrich, USA) were separately prepared. These two stock solutions were mixed with nutrient broth medium (9 $\mathrm{mL}$ ) separately, which contained $1 \times 10^{7}$ spores $\mathrm{mL}^{-1}$ of Bacillus subtilis M-9 and kept it in water bath (Eyela, Japan) at $37^{\circ} \mathrm{C}$. After a specific time interval, one milliliter sample was withdrawn and cell pellet was washed three times with normal saline, centrifuged at 10,000 rpm for 1 minute using centrifuge machine (Mikro 20 Hettich, Germany), to remove mutagen from sample [16].

\section{Mutant selection}

Total viable count was determined by the method of Eaton et al. [17]. The B. subtilis M-9 spores were treated with three different types of mutagens and prepared its hundred fold serial dilution separately to get nearly 30 colonies per plate. In the dark room, the $0.1 \mathrm{~mL}$ of these spore dilutions were streaked on nutrient agar plates (Oxoid, Hampshire, UK), that contain $0.1 \%$ triton X-100 to inhibit the growth of other bacterial colonies. All these plates were kept at $37^{\circ} \mathrm{C}$ for 48 hours in an incubator and counted the bacterial colonies in each plate [18].

Specific mutant for hyper-production of alkaline protease was selected by the method of Javed et al. [19]. All the best selected mutants were streaked on skim milk agar plates which contain skim milk ( $1 \%$ $\mathrm{v} / \mathrm{v})$, peptone $(0.5 \% \mathrm{w} / \mathrm{v}), \mathrm{NaCl}(0.5 \% \mathrm{w} / \mathrm{v})$, and agar $(2 \% \mathrm{w} / \mathrm{v})$ at $\mathrm{pH}$
9.0. The streaked plates were incubated at $37^{\circ} \mathrm{C}$ for $48 \mathrm{~h}$ and selected on the basis of bigger zone of hydrolysis as compared to control for further study [20].

\section{Cultivation of fermentation medium}

Alkaline protease was produced by B. subtilis M-9 and selected mutant in liquid state fermentation [21]. Triplicate flasks with $2 \mathrm{~g}$ agroindustrial substrate (Corn stover/banana stalk), peptone $(0.5 \%)$ and yeast extract $(0.3 \%)$ were autoclaved at $121^{\circ} \mathrm{C}$ and $15 \mathrm{lbs}$. pressure for 15 minutes. Spore suspension (Inoculum) was aseptically transferred to each flask by using sterilized pipette in the laminar air flow cabinet after cooling the medium. The flasks were incubated $\left(37^{\circ} \mathrm{C}\right)$ at $120 \mathrm{rpm}$ for 48 hours in the shaker (Sanyo- Gallenkamp, UK).

\section{Optimization of fermentation parameters}

Different parameters were optimized for hyper-production of protease with parent and mutant strains. The basal medium was fermented in triplicate flasks with parent Bacillus subtilis M-9 and mutant Bacillus subtilis BSU-5 containing selected substrate corn stover at varying $\mathrm{pH}$, temperature, inoculum size and fermentation time. The experiments were studied in that way, the parameters optimized in first experiment were continued in the next experiment $[15,16]$.

\section{Analytical procedures}

Alkaline protease activity was determined by using $1.0 \%(\mathrm{w} / \mathrm{v})$ casein solution as a substrate in $0.05 \mathrm{M}$ glycine- $\mathrm{NaOH}$ buffer at $\mathrm{pH}$ 9.0 [22]. The substrate was treated with a known amount of enzyme solution for $15 \mathrm{~min}$ at $37^{\circ} \mathrm{C}$, and absorbance was measured at $280 \mathrm{~nm}$. One proteolytic unit (PU) was defined as amount of the enzyme that released 1 ug of tyrosine $/ \mathrm{mL} / \mathrm{min}$ under the assay conditions. The total protein contents of the samples were determined by the method of Lowry et al. [23], using bovine serum albumin (BSA) as a reference standard. Glucose contents were determined according to the phenolsulfuric acid method described by Dubois et al. [24]. The biomass contents were determined by measuring the dry weight from a known amount of sample centrifuged at $9000 \mathrm{rpm}$ for $10 \mathrm{~min}$ at $4^{\circ} \mathrm{C}$, and the cell pellet was washed three times with normal saline to remove the suspended particles. The washed sample was then dried at $105^{\circ} \mathrm{C}$ till the constant weight was obtained.

\section{Determination of kinetic parameters}

Different kinetic parameters for biomass and enzyme yield were determined according to the methods described by Pirt [25] and Okpokwasili and Nweke [26]. All these kinetic parameters viz. $\mathrm{Y}_{\mathrm{p} / \mathrm{s}^{\prime}}$ $\mathrm{Y}_{\mathrm{p} / \mathrm{x}}, \mathrm{Y}_{\mathrm{x} / \mathrm{s}}, \mathrm{u}\left(\mathrm{h}^{-1}\right), \mathrm{q}_{\mathrm{s}}, \mathrm{Q}_{\mathrm{s}}, \mathrm{q}_{\mathrm{p}}$ and $\mathrm{Q}_{\mathrm{p}}$ were studied at pre-optimized culture conditions in batch fermentation process.

\section{Immobilization of mutant BSU-5}

All the immobilization processes were performed under aseptic conditions. The cell pellet of Bacillus subtilis BSU-5 were obtained in logarithmic phase of growth was collected by centrifugation at 5000 rpm in centrifuge (Mikro 20 Hettich, Germany). $0.38 \mathrm{~g}$ bacterial cells were obtained from culture mixed with $10 \mathrm{~mL}$ sodium alginate solution at a concentration of $3 \%(\mathrm{w} / \mathrm{v})$ through a sterile pipette. Beads of $2 \mathrm{~mm}$ diameter were obtained by dropping mixtures into sterile $\mathrm{CaCl}_{2}(0.1$ $\mathrm{M})$. The beads from $10 \mathrm{~mL}$ gel were used for inoculation of $25 \mathrm{~mL}$ of the production medium [14]. For entrapment in agar, $0.38 \mathrm{~g}$ wet cells were mixed with $10 \mathrm{~mL}$ of $3 \%$ agar solution at $45^{\circ} \mathrm{C}$. The mixture was allowed to quickly cool at $4^{\circ} \mathrm{C}$. Cut into $2 \times 2 \times 2 \mathrm{~mm}$ fragments and transferred to 
Citation: Javed S, Meraj M, Bukhari SA, Irfan R, Mahmood S (2013) Hyper-production of Alkaline Protease by Mutagenic Treatment of Bacillus subtilis M-9 using Agroindustrial Wastes in Submerged Fermentation. J Microb Biochem Technol 5: 074-080. doi:10.4172/1948-5948.1000103

$25 \mathrm{~mL}$ of the production medium [27]. For repeated batch experiment, the experimental set up was similar to the process as described above. Every $96 \mathrm{~h}$, immobilized cells were removed, washed with saline and recultivated into fresh medium. The process was repeated for several batches till the beads started disintegrated.

\section{Statistical analysis}

Statistical significance of the differences between mean values was assessed two way analysis of ANOVA under CRD and DMR test, using Minitab 2000 version 13.2 statistical software (Minitab Inc., Pennsylvania, USA). A probability value of $p \leq 0.05$ was considered to denote a statistically significant difference [28].

\section{Results and Discussion}

\section{Strain improvement and selection of mutants}

Mutation and screening of industrially useful microorganisms are very important for the successful development of various strains which are required in the fermentation industry [29]. Therefore, the parent strain B. subtilis M-9 was treated with different mutagens like UV irradiation, NTG ( $N$-methyl- $N$-nitro- $N$-nitrosoguinidine) and EB (ethidium Bromide), to improve its productivity. In the case of UV irradiation treatment $33.5 \%$ survival rate was obtained after 140 minutes, which decreased gradually with the increase of exposure time (Table 1). Similarly, the culture of Bacillus subtilis M-9 was treated with NTG and EB for different time intervals. 22.3\% survival rate was observed with NTG after an exposure of 140 minutes (Table 1). However, exposure of parent strain with ethidium bromide for 160 minutes gave $15.2 \%$ survivals rate (Table 1). Similar trend of decrease in survivability with increase in exposure time has also been reported by some other investigators [30-33]. All these findings indicated that the survivability of parent strain depended on the nature of the microorganism, treatment period and the type of mutagens.

\section{Selection of hyper-proteolytic mutant}

From UV treated plates, 10 mutants of 140 minutes exposure were selected for screening on skim milk agar plates. Similarly, 10 hyperproteolytic mutants from NTG and 10 from EB were selected for visualizing the efficiency of their protease activity. Total of 15 mutants (5 from each mutagenic treatment) known as positive mutants were primarily selected on the basis of bigger zone of clearance on skim milk agar plates. The results showed that mutant BSU-5 obtained at 140 minute dose of UV irradiation exhibited $48 \mathrm{~mm}$ clearance zone whereas, NTG and EB treated mutants (BSN-3 and BSE-1) was obtained $41 \mathrm{~mm}$ and $37 \mathrm{~mm}$ clearance zone, respectively (Table 2).

These mutants were further evaluated through shake flask enzyme production studies. The selected mutants from UV and chemical mutagenesis ( 5 from each category) of Bacillus subtilis M-9 were used for the production of alkaline protease, using banana stalk and corn stover in submerged fermentation for the selection of best mutant. Among theses, the maximum alkaline protease production (68.81 $\pm 1.86 \mathrm{PU} / \mathrm{mL})$ with total protein $(4.72 \pm 0.92 \mathrm{mg} / \mathrm{mL})$ and dry cell mass $(3.13 \pm 0.81 \mathrm{~g} / \mathrm{L})$ was observed for the mutant BSU-5 using corn stover (Table 3 ). The results indicated BSU-5 was the most hyper-active mutant, giving approximately 5.67 fold more alkaline protease over the parent strain $(12.54 \pm 1.10)$ in similar culture conditions. Shikha et al. [33] reported 1.44 fold alkaline protease productions by Bacillus panththenticus. However, Dutta and Bannerjee [29] observed a 2.5 fold increase in alkaline protease productivity by UV mutant pseudomonas $s p$. JNGR 242.

\begin{tabular}{|c|c|c|c|}
\hline $\begin{array}{c}\text { Treatment } \\
\text { time (Min) }\end{array}$ & $\begin{array}{c}\text { \%age of } \\
\text { survival of } \\
\text { UV treated B. } \\
\text { subtilis M-9 }\end{array}$ & $\begin{array}{c}\text { \%age of survival } \\
\text { of } \\
\text { NTG treated B. } \\
\text { subtilis M-9 }\end{array}$ & $\begin{array}{c}\text { \%age of survival of EB } \\
\text { treated B. subtilis M-9 }\end{array}$ \\
\hline 0 & 100 & 100 & 100 \\
\hline 20 & 85.7 & 87.5 & 89.6 \\
\hline 40 & 82.9 & 78.9 & 79.2 \\
\hline 60 & 73.2 & 66.4 & 69.5 \\
\hline 80 & 60.2 & 56.5 & 53.04 \\
\hline 100 & 54.4 & 46.7 & 46.9 \\
\hline 120 & 44.3 & 42.1 & 37.1 \\
\hline 140 & 33.5 & 22.3 & 29.9 \\
\hline 160 & 22.15 & 8.5 & 15.2 \\
\hline 180 & 10.2 & 4.6 & 4.8 \\
\hline
\end{tabular}

Values (Mean $\pm \mathrm{SD}$ ) are average of three samples.

CFU: Colony forming Units.

$\%$ age of Survival=(Colony count after exposure time $t) \times 100 /$ Total Colonies

Table 1: Effect of UV irradiation treatment on $\%$ age of survival for $B$. subtilis $\mathrm{M}-9$.

\begin{tabular}{|c|c|}
\hline Bacillus sub.tilis Strain & Zone of clearance $(\mathrm{mm})$ \\
\hline B. subtilis M-9 & 24 \\
\hline BSU-1 & 27 \\
\hline BSU-2 & 33 \\
\hline BSU-3 & 31 \\
\hline BSU-4 & 29 \\
\hline BSU-5 & 48 \\
\hline BSN-1 & 14 \\
\hline BSN-2 & 18 \\
\hline BSN-3 & 41 \\
\hline BSN-4 & 22 \\
\hline BSN-5 & 21 \\
\hline BSE-1 & 37 \\
\hline BSE-2 & 34 \\
\hline BSE-3 & 32 \\
\hline BSE-4 & 37 \\
\hline BSE-5 & 29 \\
\hline
\end{tabular}

BSU: UV treated Bacillus subtilis.

BSN: N-methyl-N-Nitro-N-Nitrosoguanidine treated Bacillus subtilis.

BSE: Ethidium Bromide treated Bacillus subtilis.

Temperatue, $30^{\circ} \mathrm{C}$, Incubation time $48 \mathrm{hrs}$, Medium, skim milk agar plate.

Table 2: Estimation of zone of clearance produced by B. subtilis M-9and its mutants.

\section{Optimization of fermentation parameters}

It is evident from the results that alkaline protease production is significantly affected by $\mathrm{pH}$, temperature, inoculum size and fermentation period. An appropriate initial $\mathrm{pH}$ is critical for successful fermentation process, and it varies from strain to strain. The production of alkaline protease by parent $B$. subtilis M-9 and Bacillus subtilis BSU5 mutant was carried out at varying $\mathrm{pH}$ in triplicate flasks. Maximum alkaline protease production $(70.18 \pm 1.25 \mathrm{PU} / \mathrm{mL})$ was achieved when the initial $\mathrm{pH}$ of fermentation medium was kept at 9.0 (Figure 1A). It was noted that an initial increase in $\mathrm{pH}(8-9)$, alkaline protease production was also increased, but it decreased significantly above $\mathrm{pH} 10$. Similar 


\begin{tabular}{|l|c|c|c|c|c|}
\hline Parameters & Bacillus strains & Cell Biomass (g/L) & Sugar Consumed (g/L) & Total Protein $(\mathbf{m g} / \mathbf{m L})$ & Protease Activity (PU/mL) \\
\hline \multirow{2}{*}{ Pre Optimization } & Parent & $5.87 \pm 0.91$ & $27.0 \pm 1.28$ & $5.23 \pm 1.84$ \\
\cline { 2 - 5 } & Mutant & $3.13 \pm 0.81$ & $12.12 \pm 0.75$ & $6.72 \pm 0.92$ \\
\hline \multirow{2}{*}{ Post Optimization } & Parent & $4.72 \pm 0.44$ & $23.1 \pm 2.04$ & $68.81 \pm 1.06$ \\
\cline { 2 - 5 } & Mutant & $2.89 \pm 0.21$ & $8.54 \pm 1.74$ & $23.57 \pm 1.19$ \\
\hline
\end{tabular}

Values (Mean $\pm S D$ ) are average of three samples, Analyzed individually in triplicate $(n=1 \times 3 \times 3) p \leq 0.05$

Enzyme were produced in basal medium contains initial sugar concentration $50 \mathrm{~g} / \mathrm{L}(\mathrm{w} / \mathrm{v})$.

Table 3: Summary of alkaline protease production on pre and post optimization of the fermentation process among parent Bacillus subtilis M-9 and selected Bacillus subtilis BSU-5 mutant in submerged fermentation.
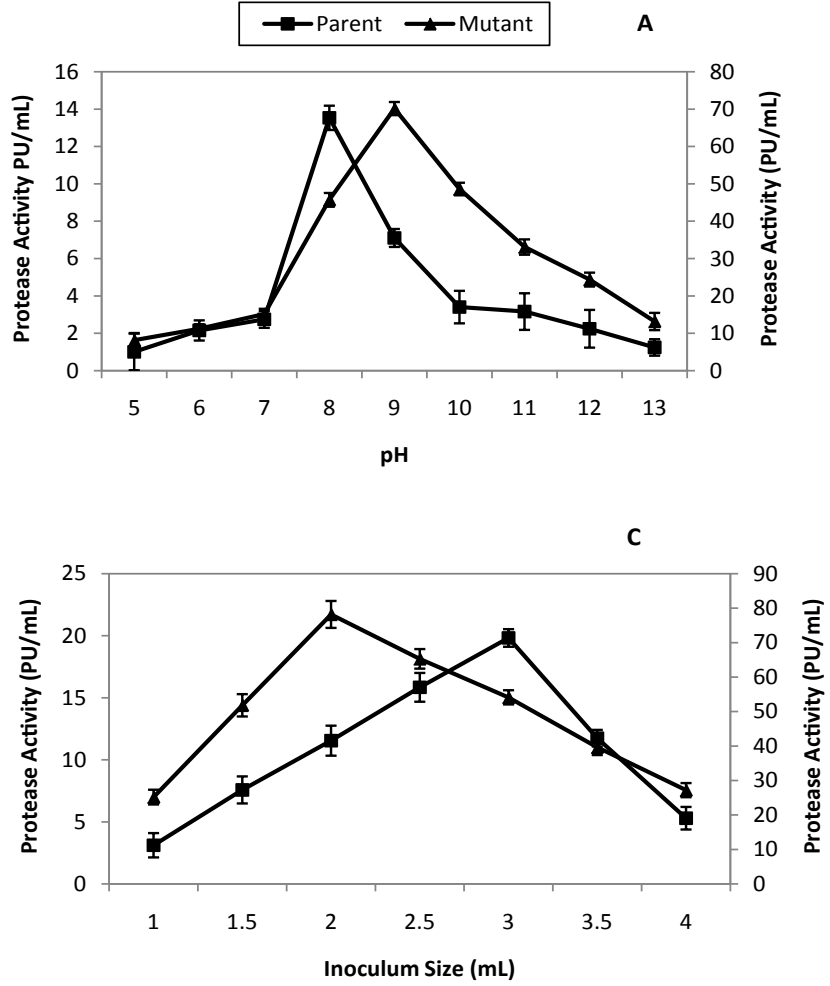

B

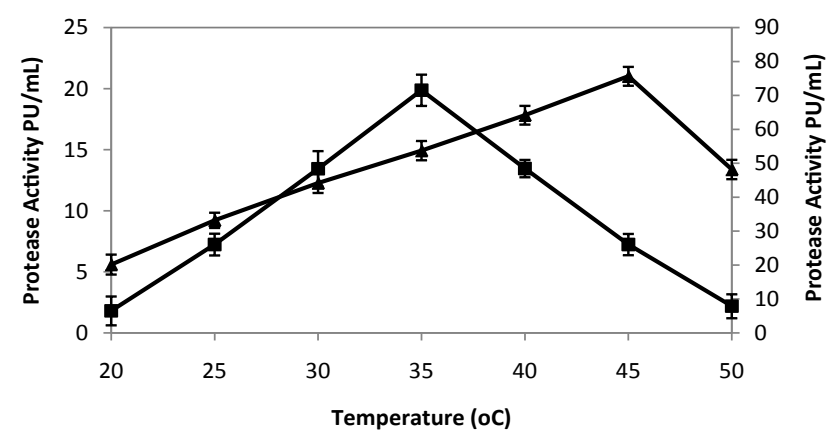

D

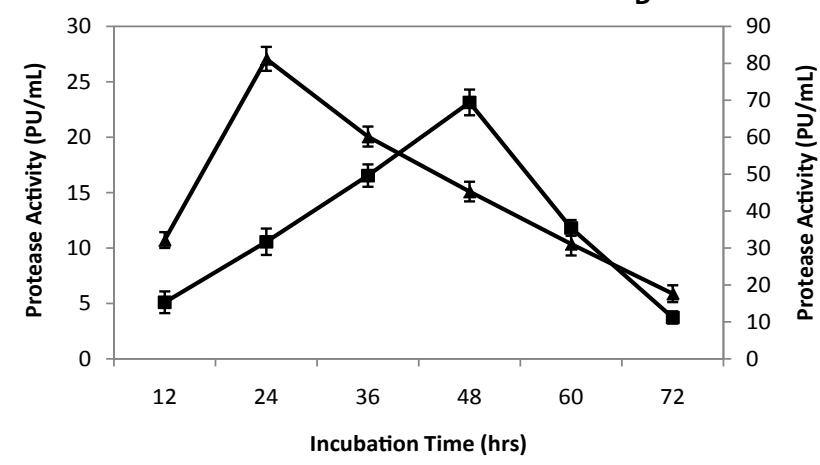

Figure 1: Comparison of effect of (A) pH (B) Temperature (C) Inoculum Size and (D) Incubation time on Alkaline Protease produced by Parent Bacillus subtilis $M-9$ (y-axis) and mutant BSU-5 (z-axis). Values (Mean \pm SD) are average of three samples, Analyzed individually in triplicate $(n=1 \times 3 \times 3) p \leq 0.05$.

trend of $\mathrm{pH}$ variation was reported by the Nadeem et al. [34]. Mukhtar and Haq [30] found optimum $\mathrm{pH} 8.5$ for alkaline protease production by Bacillus subtilis. Huang et al. [35] obtained maximum proteolytic activity at $\mathrm{pH} 10$ by Bacillus pumilus alkaline protease.

The temperature of fermentation is one of the critical factors that have direct influence on the production of secondary metabolites. Temperature affects the growth of microorganisms, and this effect is variable in media having different compositions. The alkaline Protease enzyme was produced by parent B. subtilis M-9 and Bacillus subtilis BSU-5 at different temperatures $\left(20-50^{\circ} \mathrm{C}\right)$. Parent derived alkaline protease showed $19.87 \pm 1.28 \mathrm{PU} / \mathrm{mL}$ proteolytic activity at $37^{\circ} \mathrm{C}$, whereas mutant derived maximum proteolytic activity $75.75 \pm 2.84$ $\mathrm{PU} / \mathrm{mL}$ was observed at $45^{\circ} \mathrm{C}$ (Figure 1B). This increase in optimum temperature might be due to formation of chaperones or heat shock proteins with some hydrophobic amino acids, in response to induced genetic mutation that supports high product formation at higher growth permissible temperature. Dutta and Bannerjee [29] also reported difference in incubation temperature between parent $\left(30^{\circ} \mathrm{C}\right)$ and mutant strain $\left(34^{\circ} \mathrm{C}\right)$ of pseudomonas. Mukhtar and Haq [30] obtained $37^{\circ} \mathrm{C}$ optimum temperatures for Bacillus subtilis $\mathrm{IH}-72^{\mathrm{EMS}}$ ${ }^{8}$ alkaline protease. Moreover, Nadeem et al. [32] found $60^{\circ} \mathrm{C}$ optimum temperatures for alkaline protease production by mutant strain of Bacillus pumilus.

Maximum production of alkaline protease was obtained at $3 \mathrm{~mL}$ inoculum size for parent Bacillus subtilis M-9 and $2.0 \mathrm{~mL}$ for BSU-5 $(78.81 \pm 1.65 \mathrm{PU} / \mathrm{mL})$ mutant in shake flask experiment (Figure 1C). It was also observed that further increase in inoculum size decreases the protease activity because microorganisms rapidly consume the nutrients and oxygen of the medium, which ultimately resulted in low product formation. Our findings are in good agreement with the study of Nadeem et al. [36], who also observed maximum enzyme activity with $2.0 \%$ inoculum size by Bacillus licheniformis N-2. Optimum Bacillus subtilis PCSIR-5 protease activity (107 PU/mL), with $10 \%$ inoculum size was reported by Nadeem et al. [37].

Fermentation is a useful process to obtain the maximum production of product by lowering the operational cost; a short fermentation period can contribute to the increase profitability on an industrial scale. An engineered microorganism can shorten the incubation time and high 
Citation: Javed S, Meraj M, Bukhari SA, Irfan R, Mahmood S (2013) Hyper-production of Alkaline Protease by Mutagenic Treatment of Bacillus subtilis M-9 using Agroindustrial Wastes in Submerged Fermentation. J Microb Biochem Technol 5: 074-080. doi:10.4172/1948-5948.1000103

yield of product. The optimum incubation time was 24 hours for BSU5 mutant strain with maximum alkaline protease activity of $(81.21 \pm$ $1.85 \mathrm{PU} / \mathrm{mL}$ ), whereas parent strain B. subtilis M-9 showed maximum proteolytic activity at $48 \mathrm{hrs}$ of incubation (Figure 1D). Nadeem et al. [37] reported highest alkaline protease activity at $48 \mathrm{hrs}$ by Bacillus subtilis mutant strain PCSIR-5.

\section{Kinetic parameters}

Comparison of alkaline protease production by parent Bacillus subtilis M-9 strain and mutant BSU-5 strain is presented in Table 4. Maximum proteolytic activity $(81.21 \pm 3.24 \mathrm{PU} / \mathrm{mL})$ was observed for the mutant BSU-5 strain after optimization of environmental factors. The growth parameters for pre and post optimization of growth yield coefficients, volumetric rates and specific substrate rates were also studied. The mutant strain of Bacillus subtilis BSU-5 significantly improved the values of $\mathrm{Yx} / \mathrm{s}, \mathrm{Yp} / \mathrm{x}$ and $\mathrm{Yp} / \mathrm{s}$ (5.66 PU/g, 21.98 PU/G and $0.258 \mathrm{PU} / \mathrm{g})$ over the parental strain B. subtilis $\mathrm{M}-9$ (0.46 PU/g, $2.13 \mathrm{PU} / \mathrm{g}$ and $0.217 \mathrm{PU} / \mathrm{g}$ ) before optimization, and on optimization, it was observed that these growth parameters were further improved by parent $(1.02 \mathrm{PU} / \mathrm{g}, 4.99 \mathrm{PU} / \mathrm{g}$ and $0.204 \mathrm{PU} / \mathrm{g})$, as well as mutant strain (9.50 PU/g, 28.1 PU/g and $0.338 \mathrm{PU} / \mathrm{g}$ ), respectively (Table 4). On monitoring the culture for these parameters, $\mathrm{Q}_{\mathrm{s}, \mathrm{q}} \mathrm{q}_{\mathrm{s}}$ and $\mathrm{Yx} / \mathrm{s}$, it was obtained a significant increase in these variables indicating that mutant derivative was a faster growing organism. It is also inferred from the results maximum enzyme was produced $\left(\mathrm{Q}_{\mathrm{p}}\right) 2.86 \mathrm{~g} / \mathrm{L} / \mathrm{h}$ by mutant strain of Bacillus subtilis BSU-5, and it was increased to $3.38 \mathrm{~g} / \mathrm{L} / \mathrm{h}$ on optimization of fermentation parameters. Nadeem et al. [32] reported that maximum $\mathrm{Yp} / \mathrm{x}$ and $\mathrm{Yp} / \mathrm{s}$ were $264.28 \mathrm{PU} / \mathrm{g}$ of cell biomass and 99.3 PU/g of glucose, respectively after incubation, and maximum cell growth rate 0.308 by $B$. licheniformis $\mathrm{N}-2$ strain after $8 \mathrm{~h}$ of inoculation. He et al. [38] found maximum growth rate of 0.17 by Bacillus sp. after 6 hrs of inoculation. A maximum growth rate of 0.7 , biomass $(0.023 \mathrm{~g}$ of cells/g of glucose), and product yield $(0.0211 \mathrm{U} / \mathrm{g})$ for Bacillus L21 was reported by Genckal Eand Tari [39].

\section{Immobilization of Bacillus subtilis BSU-5 mutant}

The best mutant BSU-5 was immobilized on calcium alginate and agar by entrapment method. It was obtained that effectiveness of the immobilization was less than one ( 0.768 and 0.78 for agar and calcium alginate immobilized cells, respectively), and the activity of immobilized cells was lower than free cells (Table 5). Our results were in close agreement to the Ahmad and Abdel-Fattah [14] findings, who also reported lower activity of the immobilized cells when they immobilized bacterial cells on different carriers by different method. Bacillus subtilis free cells were more efficient than immobilized cells for alkaline protease production, reported by Zaghloul et al. [40]. Less accessibility of nutrients to immobilized cells and low availability of oxygen can cause decreased activity of immobilized cells. Immobilization also changes the metabolic and morphological changes in the cells. On comparison of both carriers for immobilization, it was concluded calcium alginate beads exhibited 0.78 effectiveness factor higher than agar (i.e. 0.768).

The possibility of repeated use of immobilized cells of BSU-5 was studied. It was found that multiple uses of immobilized cells were possible as compared to free cells. Results shown in Figure 2 indicated that free cells could not retained their ability to produce alkaline protease consistently after 2 cycles with residual activity of $39.2 \%$, while immobilized cells showed the ability to produce alkaline protease

\begin{tabular}{|c|c|c|c|c|c|}
\hline \multirow{2}{*}{ Kinetic parameters } & \multirow{2}{*}{ Bacillus Strain } & \multicolumn{2}{|c|}{ Pre optimization } & \multicolumn{2}{|c|}{ Post Optimization } \\
\hline & & Parent & BSU-5 & Parent & BSU-5 \\
\hline \multirow{5}{*}{$\begin{array}{l}\text { Substrate Consumption } \\
\text { parameters }\end{array}$} & ${ }^{\mathrm{A}} \boldsymbol{\mu}\left(\mathbf{h}^{-1}\right)$ & 0.105 & 0.176 & 0.131 & 0.182 \\
\hline & ${ }^{B} Y x / s$ & 0.46 & 5.677 & 1.02 & 9.50 \\
\hline & ${ }^{c} Y p / x$ & 2.13 & 21.98 & 4.99 & 28.1 \\
\hline & ${ }^{D} q s(g / g / h)$ & 0.19 & 0.63 & 0.20 & 0.123 \\
\hline & ${ }^{E} Q s(g / L / h)$ & 1.125 & 0.16 & 0.96 & 0.355 \\
\hline \multirow{4}{*}{$\begin{array}{l}\text { Product Formation } \\
\text { Parameters }\end{array}$} & $\mathrm{F} Q \times(g / L / h)$ & 0.244 & 0.505 & 0.196 & 0.120 \\
\hline & ${ }^{G} Y p / s$ & 0.217 & 0.258 & 0.204 & 0.338 \\
\hline & ${ }^{\mathrm{H}} \mathrm{qp}$ (Product/h/g) & 0.089 & 0.916 & 0.208 & 1.17 \\
\hline & 'Qp (Product/L/h) & 0.5225 & 2.86 & 0.98 & 3.38 \\
\hline
\end{tabular}

Enzyme were produced in basal medium contains initial sugar concentration is $50 \mathrm{~g} / \mathrm{L}(\mathrm{w} / \mathrm{v})$.

${ }^{A} \mu\left(h^{-1}\right)$, Specific Growth rate

BYx/s, Enzyme produced/g glucose consumed

${ }^{\mathrm{c}} \mathrm{Yp} / \mathrm{x}$, Enzyme produced/g cell formed

${ }^{D} \mathrm{qs}(\mathrm{g} / \mathrm{g} / \mathrm{h}), \mathrm{g}$ sugar consumed/ $\mathrm{g}$ cells/h

${ }^{\mathrm{E}} \mathrm{Qs}(\mathrm{g} / \mathrm{L} / \mathrm{h})$, g sugar consumed/L/h

${ }^{\mathrm{F} Q x}(\mathrm{~g} / \mathrm{L} / \mathrm{h}), \mathrm{g}$ cells formed/L/h

GYp/s, Cell formed/g sugar consumed

${ }^{H}$ qp (Product/g/h), Enzyme produced/g cells/ h

'Qp(Product/L/h), Enzyme produced/L/h

Table 4: Comparison of Kinetic parameters for alkaline protease production among parent Bacillus subtilis M-9 and selected Bacillus subtilis BSU-5 mutant in submerged fermentation.

\begin{tabular}{|l|l|l|}
\hline Carrier & Protease Activity (PU/mL) & Effectiveness factor of immobilization $^{\mathbf{A}}$ \\
\hline Free cells & $81.21 \pm 3.24$ & 1.00 \\
\hline Agar & $62.41 \pm 1.24$ & 0.768 \\
\hline Calcium alginate & $64.73 \pm 2.28$ & 0.78 \\
\hline
\end{tabular}

Values (Mean $\pm S D$ ) are average of three protease production samples, Analyzed individually in triplicate $(n=1 \times 3 \times 3) p \leq 0.05$.

${ }^{A}$ Activity of immobilized cells/activity of the free cells of the same amount.

Table 5: Production of alkaline protease by free and immobilized Bacillus subtilis BSU-5 cells. 


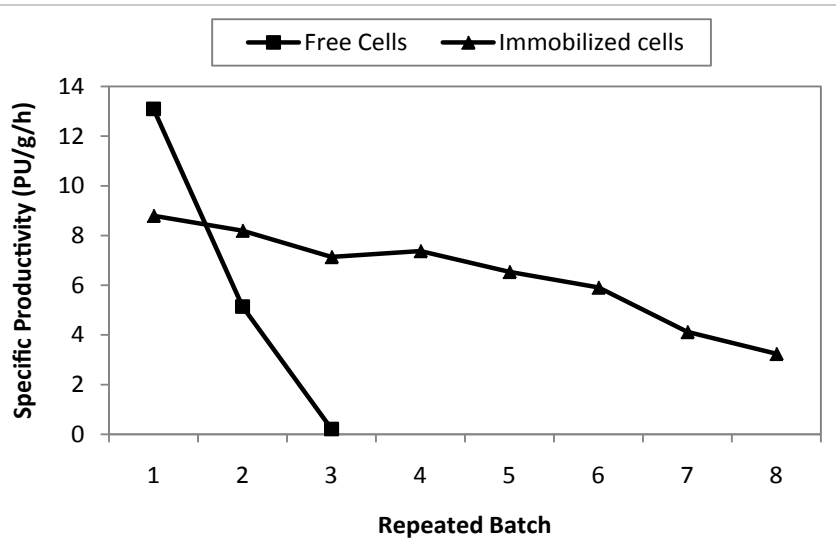

Figure 2: Alkaline protease productions by free and immobilized cells by repeated batch fermentation of Bacillus subtilis BSU-5.

after six cycles with $67 \%$ residual activity. This loss in activity was due to destruction of cells, as well as autolysis during the centrifugation and washing process. Adinarayana et al. [41] reported immobilized B.subtilis PE-11 alginate beads retained their activity for 9 batches. Wool immobilized Bacillus licheniformis ATTC 21415 was useful for 5 batches reported by Ahmed and Abdel-Fattah [14].

\section{Conclusion}

The results of the present investigation revealed that among different mutagenic treatments of Bacillus subtilis M-9 for hyperproduction of alkaline protease using agroindustrial wastes, BSU5 mutant was selected as hyper proteolytic mutant after extensive screening. The present data would certainly help to ascertain the ability of BSU-5 mutant as potential source of hyper proteolytic enzyme to be used in detergents, tanning and other industries. The immobilization of BSU-5 mutant cells would be helpful for repeated use of these cells for efficient alkaline protease production.

\section{Acknowledgement}

Authors are thankful to Dr. Sajjad-ur-Rehman, Institute of microbiology, University of Agriculture, Faisalabad, Pakistan for providing parent Bacillus subtilis M-9 strain. This paper is part of the M.Phil. research work of Rao Irfan.

\section{References}

1. Singh A, Singh N, Bishnoi NR (2009) Production of cellulases by Aspergillus heteromorphus from wheat straw under submerged fermentation. Int J Env Sci Eng 1: 23-26.

2. Mojsov K (2010) Application of solid state fermentation for cellulase enzyme production using Trichoderma viride. Perspect Innov Econ Bus 5: 108-110.

3. Mussatto SI, Teixeir JA (2010) Increase in the fructooligosaccharides yield and productivity by solid-state fermentation with Aspergillus japonicus using agro industrial residues as support and nutrient source. Biochem Eng J 53: 154-157.

4. Chellappan S, Jasmin C, Basheer SM, Elyas KK, Bhat SG, et al. (2006) Production, purification and partial characterization of a novel protease from marine Engyodontium album BTMFS10 under solid state fermentation. Proc Biochem 41: 956-961.

5. Prakasham RS, Rao CS, Sarma PN (2006) Green gram husk-an inexpensive substrate for alkaline protease production by Bacillus $\mathrm{sp}$. in solid-state fermentation. Biores Tech 97: 1449-1454.

6. Boominadhan U, Rajakumar R, Sivakumar PKV, Melvin MJ (2009) Optimization of protease enzyme production using Bacillus sp. isolated from different wastes. Bot Res Intl 2: 83-87.

7. Rani MR, Prasad NN, Sambasivarao KRS (2012) Optimization of cultural conditions for the production of alkaline protease from a mutant Aspergillus Flavus AS2. Asian J Exp Biol Sci 3: 565-576.
8. Jameel A, Mohammad MK (2011) Production and characterization of alkaline protease from locally isolated Alkaliphilic Bacillus species. Int J Eng Sci Tech 3: $4596-4603$

9. Asif M, Hussain A, Ali MA, Rasool M (2012) Scale up studies for the production of protease enzyme using Bacillus subtilis adopting response surface methodology. Afr J Microb Res 6: 2120-2128.

10. Adinarayana K, Bapi R, Ellaiah $P$ (2004) Investigation on alkaline protease production with $B$. subtilis PE-11 immobilized in calcium alginate gel beads. Proc Biochem 39: 1331-1339.

11. Prabakaran G, Hoti SL (2008) Immobilization of alginate-encapsulated Bacillus thuringiensis var israelensis containing different multivalent counterions for mosquito control. Curr Microb 57: 111-114.

12. Beshay U (2003) Production of alkaline protease by Teredinobacter turnirae cells immobilized in Ca alginate beads. Afr J Biotech 2: 60-65.

13. Karandikar S, Prabhune A, Kalele SA, Gosavi SW, Kulkarni SK (2006) Immobilization of thermotolerant Kluyveromyces marxianus on silica aeroge for continuous production of invertase syrup. Res J Biotech 1: 16-19.

14. Ahmed SA, Abdel-Fattah AF (2010) Production of Bacillus licheniformis ATCC 21415 alkaline protease in batch, repeated batch and continuous culture. Malay J Microb 6: 156-160

15. Javed S, Asghar M, Sheikh MA, Nawaz H (2010) Strain improvement through UV and chemical mutagenesis for enhanced citric acid production in molasses based solid state fermentation. Proc Int J Food Tech 24: 165-169.

16. Meraj M, Rahman K, Jamil A, Ashraf M, Rajoka MI, et al. (2012) Bacillus subtilis Improvement through UV and chemical mutagenesis for indigenously hyperproduced urate oxidase. Pak J lif Soc Sci 10: 123-12.

17. Eaton AD, Clesceri LS, Rice EW, Greenberg AE (2005) Standard methods fo the examination of water and wastewater. (21 ${ }^{\text {st }}$ Edn.). American Public Health Association, USA.

18. Nadeem M, Qazi JI, Baig S (2009) Effect of aeration and agitation rates on alkaline protease production by Bacillus licheniformis UV-9 mutant. Turk J Biochem. 34: 89-96.

19. Javed S, Asghar M, Sheikh MA, Nawaz H, Jamil A (2011) Enhanced citric acid production by Aspergillus niger EB-3 mutant using an inert solid support in molasses medium. Afr J Biotech 10: 11784-11791.

20. Khattab AA, Bazaraa WA (2005) Screening, mutagenesis and protoplast fusion of Aspergillus niger for the enhancement of extracellular glucose oxidase production. J Ind Microb Biotech 32: 289-294.

21. Fieudrek J, Paszezynski A, Ginalska G, llezuk Z (1987) Selectiom of amylolytically active Aspergillus niger mutants to 2-deoxy-D-glucose. Zent Mikrob 142: 407-412.

22. Yang SS, Huang Cl (1994) Proteases production by Amylolytic fungi in solid state fermentation. J Chin Agri Chem Soc 32: 589-601.

23. Lowry OH, Roserbrough N, Farr AL, Randall R (1951) Protein measurement with folin phenol reagent. J Biol Chem 193: 265-275.

24. Dubois M, Gilles KA, Hamilton JK, Rebers PA, Smith F (1956) Colorimetric method for determination of sugars and related substances. Anal Chem 28 350-356.

25. Pirt SJ (1975) Principles of Microbes and cell cultivation. In: Parameters of growth and analysis of growth data, Blackwell Scientific Publications, London, UK.

26. Okpokwasili GC, Nweke CO (2005) Microbial growth substrate utilization kinetics. Afr J Biotech 5: 305-317.

27. Cheetham PSJ, Garrett C, Clark J (1985) Isomaltulose production using immobilized cells. Biotech Bioeng 27: 471-481.

28. Steel RGD, Torrie JH, Dickey D (1997) Principles and procedures of statistics: A biometrical approach. (3rd Edn.), McGraw Hill Book, USA.

29. Dutta JR, Bannerjee R (2006) Isolation and characterization of a newly isolated Pseudomonas mutant for protease production. Braz Arch Biol Tech 49: 37-47.

30. Mukhtar H, Haq I (2008) Production of alkaline protease by Bacillus subtilis and its applications as deplating agents in leather processing. Pak J Bot 40: 1673-1679.

31. Meraz IM, Choudhury T, Haq MM (2006) Optimization of mutation conditions of 
Citation: Javed S, Meraj M, Bukhari SA, Irfan R, Mahmood S (2013) Hyper-production of Alkaline Protease by Mutagenic Treatment of Bacillus subtilis M-9 using Agroindustrial Wastes in Submerged Fermentation. J Microb Biochem Technol 5: 074-080. doi:10.4172/1948-5948.1000103

Bacillus sp. to increase the yield of alkaline protease. J Hum Lif Sci 4: 43-50.

32. Nadeem M, Qazi JI, Baig S (2010) Enhanced production of alkaline protease by a mutant of Bacillus licheniformis n-2 for dehairing. Braz Arch Biol Tech 53: 1015-1025.

33. Shikha, Sharan A, Darmwal NS (2007) Improved production of alkaline protease from a mutant of alkalophilic Bacillus pantotheneticus using molasses as a substrate. Biores Tech 98: 881-885

34. Nadeem M, Qazi JI, Syed Q, Baig S (2008) Optimization of process parameters for alkaline protease production by Bacillus licheniformis $\mathrm{N}-2$ and kinetics studies in batch fermentation. Turk J Biol 32: 243-251.

35. Huang Q, Peng Y, Li X, Way H, Zhang Y (2003) Purification and characterization of an extracellular alkaline serine protease with dehairing function for Bacillus pumilus. Curr. Microb 46: 169-173.

36. Nadeem M, Qazi JI, Baig SJ, Syed QA (2007) Studies on commercially important alkaline protease from Bacillus licheniformis $\mathrm{N}-2$ isolated from decaying organic soil. Turk J Biochem 32: 171-177.
37. Nadeem M, Baig SJ, Syed QA, Qazi JI (2006) Microbial production of alkaline proteases by locally isolated Bacillus subtilis PCSIR-5. Pak J Zool 38: 109-114.

38. He G, Chen Q, Ju X (2004) Improved elastase production by Bacillus $s p$ EL31410-Further optimization and kinetics studies of culture medium for batch fermentation. J Zhej Univ Sci 5: 149-156.

39. Genckal H, Tari C (2006) Alkaline protease production from alkalophilic Bacillus $s p$. isolated from natural habitats. Enz Microb Tech 39: 703-710.

40. Zaghloul TI, Hendawy HM, El-Assar S, Mostafa MH (2002) Enhanced stability of the cloned Bacillus subtilis alkaline protease gene in alginate-immobilized $B$. subtilis cells. Enz Microb Tech 30: 862-866.

41. Adinarayana K, Jyothi B, Ellaiah P (2005) Production of alkaline protease with immobilized cells of Bacillus subtilis PE-11 in various matrices by entrapment technique. Pharm Sci Tech 48: 391-397. 